\title{
PERSEPSI DAN PERILAKU KONSUMEN \\ TERHADAP ONLINE SHOPPING
}

\author{
OBSERVASI LAPANGAN
}

Disusun guna memenuhi Tugas mata Kuliah Manajemen Pemasaran

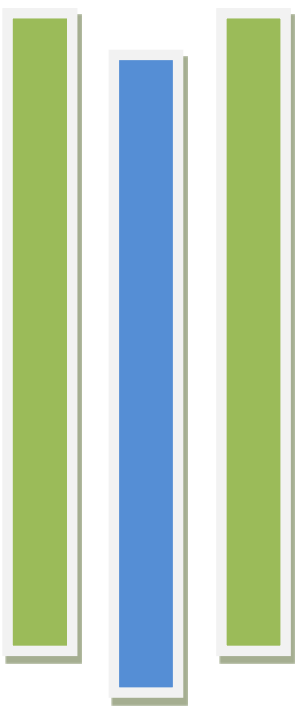

Disusun :

$\mathbf{O}$

$\mathbf{L}$

$\mathbf{E}$

H

MULYADI

NIM : 012723349

UNIVERSITAS TERBUKA

2019

KATA PENGANTAR 
Puji Syukur kepada Tuhan Yang Maha Esa, karena atas limpahan Rahmatnya, Penulisan Tugas Manajemen Pemasaran yang berjudul "Memahami Perilaku Konsumen Dalam Berbelanja Online" dapat terselesaikan dengan baik. Penulisan Observasi Lapangan ini bertujuan untuk memenuhi Tugas Manajemen Pemasaran. Observasi Lapangan ini ditulis hasil penyusunan data - data yang diperoleh dari buku - buku, artikel - artikel, serta informasi media yang berhubungan dengan tema diatas, tak lupa juga saya ucapkan terima kasih kepada Bapak / Ibu yang memberikan masukan sehingga dapat diselesaikannya observasi lapangan ini. Saya mengharapkan kritik dan saran demi perbaikan dan penyempurnaan observasi lapangan ini, dan semoga observasi lapangan ini dapat bermanfaat bagi Pihak yang membutuhkan dan bermanfaat bagi semua pembaca.

Sambas , 18 Mei 2019

MULYADI 


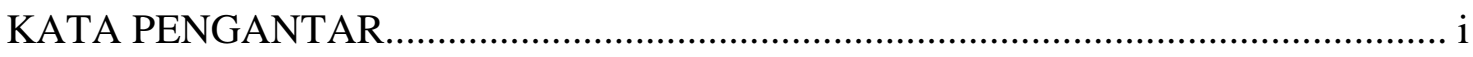

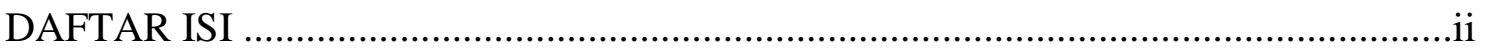

\section{BAB I}

PENDAHULUAN
A. Latar Belakang. 1

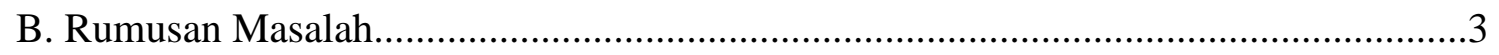

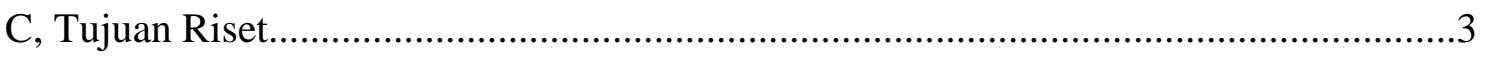

\section{BAB II}

\section{PEMBAHASAN}

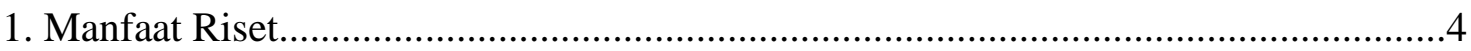

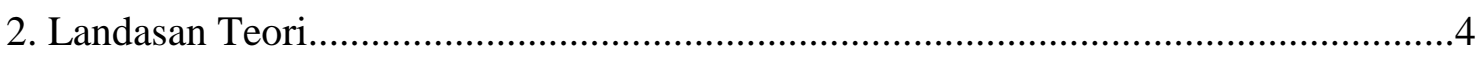

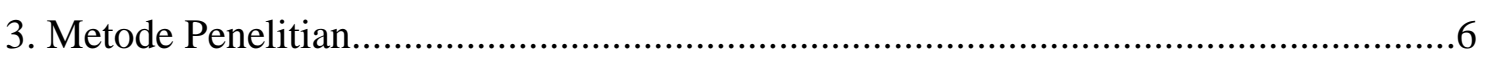

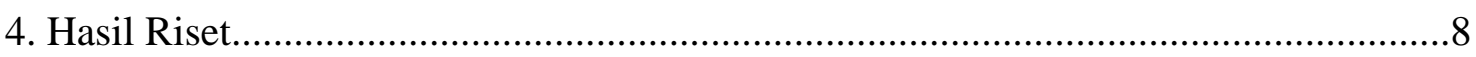

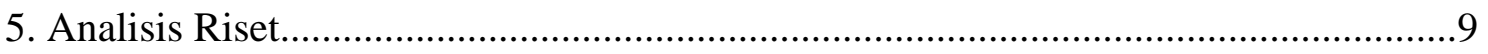

\section{BAB III}

PENUTUP

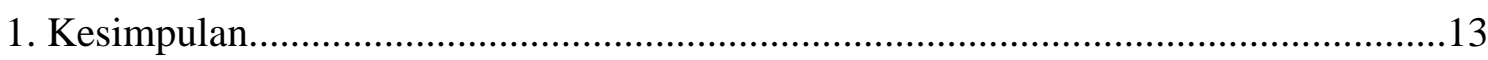

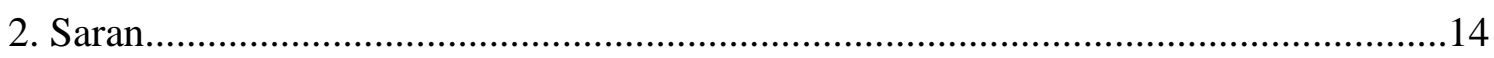

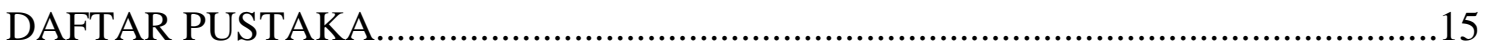

\section{LAMPIRAN GAMBAR / PHOTO KONSUMENNYA}

ii

\section{BAB I}




\section{PENDAHULUAN}

Belanja online adalah proses dimana konsumen langsung membeli barang atau jasa dari penjual secara real-time, tanpa perantara layanan, melalui Internet. Jika layanan perantara hadir proses ini disebut perdagangan elektronik. Sebuah toko online, eshop, e-toko, toko internet, webshop, webstore, toko online, atau toko virtual membangkitkan analogi fisik membeli produk atau jasa di toko bata-dan-mortir atau di pusat perbelanjaan. Proses ini disebut Business-to-Consumer (B2C) belanja online. Ketika bisnis membeli dari bisnis lain yang disebut Business-to-Business (B2B) belanja online. Baik B2C dan B2B belanja online bentuk e-commerce. Kata kunci : Memanjakan konsumen dengan penjualan on line shooping adalah modal kepercayaan.

\section{A. LATAR BELAKANG}

Kemunculan saluran belanja baru, yaitu melalui media internet, membuat banyak perusahaan mulai mendirikan tokonya secara online. Belanja online dalam prakteknya masih terdapat banyak kekurangan terutama dalam menarik minat konsumen untuk membeli. Beberapa ahli menyatakan bahwa perilaku konsumen toko offline dan toko online tidak jauh berbeda, sehingga para pemasar dapat menggunakan cara yang sama seperti yang dilakukan oleh toko tradisional untuk menarik minat beli konsumen. Penelitian ini meneliti perilaku konsumen atas saluran belanja online yang memiliki faktor-faktor pengaruh seperti, faktor psikologis, faktor budaya, faktor pribadi dan faktor sosial yang nantinya akan mengarahkan konsumen pada keputusan pembelian.

Belanja online adalah proses dimana konsumen langsung membeli barang atau jasa dari penjual secara real-time, tanpa perantara layanan, melalui Internet. Jika layanan perantara hadir proses ini disebut perdagangan elektronik. Sebuah toko online, eshop, e-toko, toko internet, webshop, webstore, toko online, atau toko virtual membangkitkan analogi fisik membeli produk atau jasa di toko bata-dan-mortir atau di pusat perbelanjaan. Proses ini disebut Business-to-Consumer (B2C) belanja online. Ketika bisnis membeli dari bisnis lain yang disebut Business-to-Business (B2B) belanja online. Baik B2C dan B2B belanja online bentuk e-commerce. 
1. Perubahan mendasar yang ikut mempengaruhi perilaku konsumen ikut dipicu dengan perkembangan teknologi informasi yang semakin berkembang dengan pesat memasuki abad ke-21. Perkembangan internet dalam dekade terakhir telah membawa perubahan yang radikal pada dunia perdagangan di berbagai jenis komoditas (Lin dan Sun, 2009).

2. Konsumen saat ini dapat memilih untuk melakukan pembelian secara online atau offline. Kombinasi antara brick-and-mortar dan teknologi informasi menyebabkan konsumen dapat mencari informasi tentang produk di internet, namun melakukan pembelian produk di brick-and-mortar stores, tetapi juga ada konsumen yang melihat produk di toko berbangunan fisik, namun melakukan pembelian secara online (Seock dan Norton, 2007). Brick-and-mortar dianggap lebih nyata karena memiliki lokasi dan bangunan fisik yang dapat dikunjungi konsumen dan dapat memenuhi kebutuhan lima panca indera konsumen. Sedangkan toko online memiliki lokasi yang virtual, dipisahkan jarak, dan interaksi dilakukan dengan mesin.

Saat ini sangat mudah untuk menemukan toko online yang menawarkan produknya melalui situs pribadi, jaringan social seperti Facebook, Twitter, dan Instagram, Blog, e-mail, mailing list (Milis), situs komunitas seperti Kaskus dan melalui situs jual beli seperti Tokobagus. Dengan mengetikkan kata kunci tertentu di mesin pencari, pengguna internet dapat dengan mudah menemukan informasi produk dan harga dari beberapa penjual sekaligus (Jiang, 2002). Beragam produk dapat dibeli melalui media internet, diantaranya pakaian, tas, sepatu, buku, tiket pesawat, sampai barang -barang elektronik. Penelitian ini secara khusus bertujuan untuk meneliti atau melakukan riset terhadap perilaku konsumen pada online shopping, dimana online shopping merupakan tren baru yang berlangsung beberapa tahun terakhir ini, dan sudah ada sebagian konsumen yang mengadopsi metode belanja ini ; sementara masih ada pula yang mempertahankan metode belanja konservatif atau tradisional dengan membeli langsung di toko fisik atau melalui sales / katalog fisik / MLM. 
Rumusan masalah yang akan diteliti dalam penelitian ini adalah :

1. Bagaimanakah persepsi konsumen terhadap online shopping?

2. Apa yang menjadi motivasi konsumen untuk melakukan atau tidak melakukan online shopping?

3. Bagaimana model perilaku belanja online shopping?

\section{TUJUAN RISET}

Tujuan riset ini adalah untuk meneliti perilaku konsumen dalam fenomena belanja online ( online shopping) yang saat ini sedang menarik perhatian. Adapun secara spesifik tujuan riset ini adalah berusaha untuk :

1. Mengetahui persepsi konsumen terhadap online shopping

2. Mengetahui apa yang memotivasi konsumen untuk melakukan atau tidak melakukan online shopping.

3. Mengetahui model perilaku belanja online shopping. 


\section{BAB II \\ PEMBAHASAN}

\section{MANFAAT RISET}

a. Bagi Akademis

Diharapkan penelitian ini dapat menjadi kontribusi yang dapat melengkapi teori - teori mengenai Perilaku Konsumen yang terdapat pada naskah dan literatur akademik, khususnya mengenai Online Shopping.

\section{b. Bagi Pemilik Toko Online}

Penelitian ini dapat memberikan kontribusi untuk mengetahui gambaran perilaku konsumen dalam memilih untuk melakukan atau tidak melakukan belanja online, apa motivasi yang mendasarinya, dan bagaimana model perilakunya. Sehingga hasil penelitian ini dapat dimanfaatkan untuk menyusun strategi - strategi yang diperlukan dalam memenangkan persaingan di market space.

\section{c. Bagi Peneliti lain}

Penelitian ini nantinya diharapkan dapat digunakan sebagai acuan atau pandangan untuk penelitian yang akan datang sehingga akan membantu untuk mempercepat dan melengkapi penelitian yang diperlukan selanjutnya.

\section{LANDASAN TEORI}

\section{Perilaku Konsumen}

Fokus dari studi perilaku konsumen terletak pada proses pertukaran, secara formal didefinisikan sebagai proses yang melibatkan transfer dari sesuatu yang berwujud atau tidak berwujud, nyata atau simbolik, antara dua atau lebih pelaku sosial. Masalah utama ketika peneliti menginvestigasi pertukaran adalah penjelasan mengapa seseorang bersedia melepaskan sesuatu miliknya untuk menerima sesuatu yang lain sebagai balasannya, (Kotler at al., 2006). 


\section{A. Persepsi}

Persepsi didefinisikan sebagai proses dimana seorang individu memilih, mengorganisasikan, dan menginterpretasikan rangsangan menjadi gambaran yang berarti dan koheren tentang dunia. Dapat digambarkan sebagai "bagaimana kita melihat dunia sekitar kita". Dua individu mungkin terkena rangsangan yang sama dalam kondisi yang jelas sama tetapi bagaimana setiap orang mengenali, memilih, mengatur, dan menafsirkan rangsangan ini adalah proses yang sangat individu berdasarkan kebutuhan setiap orang, nilai-nilai, dan harapan (Schiffman and Kanuk, 2010).

B. Motivasi Konsumen

Motivasi berasal dari kata "motive" yaitu sesuatu yang membuat seseorang bertingkah laku tertentu atau paling tidak berkeinginan untuk besikap tertentu. Dengan demikian, motivasi merupakan hal-hal yang menyebabkan, menyatukan, serta mempertahankan orang berprilaku tertentu. Tanpa adanya kebutuhan tidak aka nada motivasi. Motivasi pada seseorang akan mewujudkan suatu prilaku yang diarahkan pada tujuan mencapai kepuasan. Jadi dengan kata lain setiap prilaku atau kegiatan seseorang diarahkan untuk memenuhi tujuan tertentu yang berkaitan dengan kebutuhan dalam memperoleh kepuasan. Setiap kegiatan yang dilakukan oleh seseorang itu didorong oleh suatu kekuatan dari dalam diri orang tersebut. Kekuatan pendorong itulah yang disebut dengan motivasi. (Reksohadiprojo dan Handoko,1986).

\section{Model Perilaku Belanja}

Untuk dapat memahami perilaku belanja dari konsumen, Kotler (2006) mengemukakan bahwa terdapat tiga tahapan yang harus dilalui, yaitu :

a. Aktivitas promosi dan stimulus lain

b. Kotak hitam pembeli

c. Respon dari pembeli 
Model perilaku belanja konsumen menurut Kotler (2006) :

2. Online Shopping

\section{A. Pengertian Online Shopping}

Belanja online juga di sebut dengan istilah perdagangan elektronik (Electronic commerce atau e-commerce) adalah penyebaran, pembelian, penjualan, pemasaran barang dan jasa melalui sistem elektronik seperti internet atau televisi, www atau jaringan komputer Lainnya. Pengertian Electronic Commerce ( EC) juga dapat didefinisikan konsep baru yang bisa digambarkan sebagai proses jual beli barang atau jasa pada World Wide Web Internet Shim et al (2000) dalam Suyanto (2003:11) atau proses jual beli produk, jasa dan informasi melalui jaringan informasi termasuk internet menurut Turban et al (2000) dalam Suyanto (2003:11).

\section{METODE PENELITIAN}

\section{A. JENIS RISET}

Penelitian ini menggunakan metode deskriptif, yaitu metode prosedur pemecahan masalah yang diselidiki dengan menggambarkan atau melukiskan keadaan objek penelitian pada saat sekarang berdasarkan fakta - fakta yang tampak atau sebagaimana adanya, yaitu dengan melihat kasus yang berkembang saat ini (Nawawi \& Matini, 1992 : 27). Penelitian ini menggunakan penelitan kualitatif yang memiliki relasi dengan analisis data visual dan data verbal yang merefleksikan pengalaman.

\section{B. SUBYEK PENELITIAN}

Subyek penelitian adalah sesuatu yang kedudukannya sangat sentral karena pada subyek penelitian terdapat data tentang variabel yang akan diamati. Adapun yang menjadi subyek penelitian ini, yaitu masyarakat secara keseluruhan, baik yang sudah pernah melakukan belanja online maupun yang belum pernah, karena riset ini ingin mengetahui bagaimana perilaku konsumen terhadap online shopping. 


\section{JENIS DATA}

Berdasarkan sumbernya, data kualitatif dapat dikelompokkan menjadi data historis, data teks, data kasus dan data pengalaman individu. Pada penelitian ini, data yang akan terkumpul termasuk dalam jenis data historis dan data pengalaman individu. Data historis, yaitu data kualitatif yang berasal dari sumber - sumber sejarah, misalnya tulisantulisan sejarah, artefak-artefak, dan lainnya. Pada penelitian ini yang dimaksud dengan data pengalaman individu.

\section{METODE PENGUMPULAN DATA}

Interview, Sesuai dengan pengertian interview yang memiliki pengertian sebagai teknik pengumpulan data dengan cara pertukaran verbal tatap muka yang dilakukan oleh seorang pewawancara terhadap respondennya. Pewawancara berupaya untuk memperoleh informasi atau ungkapan-ungkapan pendapat, serta keyakinan dari subjek penelitian (Maccoby dan Maccoby dalam Minichiello, dkk., 1995).

1. Observasi, Metode dimana peneliti mengamati langsung objek yang diteliti. (Kriyantono, $2007: 66$ ).

\section{E. METODE ANALISIS DATA}

Analisis data adalah proses mengatur urutan data, mengorganisasikannya ke dalam suatu pola, kategori, dan satuan uraian data. Kegiaatan analisis atau analisis data merupakan upaya mencari data secara sistematis dari data catatan hasil observasi, wawancara, dan lainnya untuk meningkatkan pemahaman peneliti tentang kasus yang diteliti dan mengkajinya sebagai temuan. Data yang valid diperoleh dengan penyederhanaan hasil perolehan data yang dilakukan dengan model interactive yang disusun secara terinci dan sistematis., yaitu dengan menggunakan langkah-langkah berikut

1. Reduksi Data, merupakan suatu proses dimana data yang diperoleh dari lapangan tersebut dilakukan reduksi, dirangkum, dipilih hal-hal yang pokok, dan difokuskan pada hal-hal yang penting, serta disusun secara sistematis dengan tujuan agar data tersebut menjadi lebih mudah dipahami dan dikendalikan. 
2. Display data merupakan tampilan atau laporan yang merupakan informasi yang diperoleh sebagai hasil reduksi data yang memungkinkan adanya penarikan kesimpulan dan pengambilan tindakan.

3. Penarikan kesimpulan / verifikasi, dalam penelitian kualitatif, penarikan kesimpulan telah dilakukan sejak penelitian itu dimulai dimana peneliti mencari makna dari data yang dikumpulkannya dan melakukan penarikan kesimpulan.

\section{HASIL RISET}

A. Profil Responden / Narasumber

Penelitian ini menghimpun informasi dari 10 narasumber, dengan profil sebagai berikut:

- Jenis kelamin : 4 pria \& 6 wanita

- Usia: 23 - 39 tahun

- Pendidikan: SD , SLTP, SMK , S1-S2

- Pekerjaan: Wiraswasta, Ibu Rumah tangga, dan mahasiswa

- Pendapatan : Rp 850.000,-- - Rp 5.000.000,-/ bulan

- 10 orang responden pernah melakukan online shopping;

B. Temuan yang Didapat

Berdasarkan hasil pengumpulan data yang dilakukan melalui pengumpulan jawaban atas responden, maka dapat diperoleh informasi tentang tanggapan respoden pada masing-masing pertanyaan penelitian. Dari profil responden di atas, sebagian besar pengguna internet dan yang pernah melakukan online shopping adalah kelompok narasumber dari Generasi Y, yaitu mereka yang lahir antara tahun 1978 - 1994 atau pada saat ini (tahun 2012) usia mereka adalah 18 - 34 tahun. Hanya narasumber 4 yang tidak pernah mengenal internet, dimana responden tersebut berusia 39 tahun atau lahir pada tahun 1973, yang termasuk Generasi X. Dengan demikian, responden ini mewakili pendapat Kotler dan Keller (2009). 
Menurut Kotler dan Keller (2009), setiap generasi sangat dipengaruhi oleh lingkungan tempat mereka dibesarkan, seperti musik, film, politik, dan kejadian-kejadian yang terjadi pada periode tersebut. Generasi yang lahir antara tahun $1978-1994$ dijuluki Generasi Y. Generasi Y pada umumnya sudah mengenal kabel sejak lahir, seperti bermain game komputer, mengarungi World Wide Web, dan men-download musik, terhubung dengan teman via pesan singkat (SMS) dan mobile phone.

\section{ANALISIS HASIL RISET}

A. Persepsi

Pembelian melalui internet (online shopping) dipersepsikan sebagai sesuatu yang menyenangkan dan mudah oleh narasumber yang pernah melakukan online shopping. Sedangkan pada responden yang buta terhadap dunia internet, melakukan pembelian secara online dianggap sebagai momok yang menakutkan. Hal tersebut didukung oleh fakta - fakta maraknya kasus penipuan di internet yang salah satunya bermodus transaksi online. Lamanya interaksi narasumber terhadap dunia internet tidak mempengaruhi kemauan untuk mengadaptasi tren online shopping.

\section{B. Motivasi Konsumen}

Motivasi konsumen dipengaruhi oleh faktor dari dalam dan faktor dari luar konsumen itu sendiri. Faktor dari dalam yang mempengaruhi adalah seperti alasan kepraktisan. Bagi konsumen yang belum termotivasi untuk mencoba melakukan belanja online, motivasi tersebut belum dapat ditumbuhkan karena tidak ada niat dan nyali untuk melakukan suatu langkah baru. Dimana responden ini mewakili kelompok Generasi $\mathrm{X}$ yang resisten untuk berubah. Profil responden 10 ini merupakan tipikal ibu rumah tangga dari suku Jawa yang patuh dengan suami, dan tidak memiliki pekerjaan lain selain mengurus anak dan rumah tangga, memiliki jiwa sosial dan menjunjung tinggi nilai - nilai kebersamaan dan kerukunan. Sehingga dalam pernyataannya, konsumen tipe ini mengatakan bahwa mereka lebih suka berbelanja secara konvensional, yang dicirikan : 
- Dapat menyentuh barang yang akan dibeli

- Dapat berinteraksi dengan penjual untuk menjalin keakraban

- Dapat melakukan negosiasi secara langsung ( entah menawar harga atau memperlunak cara pembayaran )

Selain itu, tipe konsumen yang diwakili responden 10 adalah tipe konsumen yang memiliki keterbatasan yang dibutuhkan untuk memfasilitasi transaksi online, seperti misalnya :

- Ketiadaan rekening tabungan

- Ketidakmampuan terhadap penguasaan komputer dan internet

- Keterbatasan dana untuk mencoba metode transaksi lain, melalui online. Motivasi dari luar yang mempengaruhi subyek untuk berbelanja online adalah faktor produk, harga, tempat, dan promosi yang ditawarkan.

C. Model Perilaku Pembelian

Sedangkan perbedaan perilaku pembelian online tidak terbatas pada gender pria atau wanita. Yang membedakan adalah pria cenderung memilih pembelian produk yang spesifik, sesuai dengan kebutuhan atau yang dapat mendukung pekerjaannya. Misalnya, Narasumber 1 membeli produk - produk sparepart komputer, karena dapat mendukung pekerjaannya sebagai online shopper khusus sparepart komputer maupun pekerjaannya di dunia nyata. Akan tetapi, pembelian pada wanita adalah produk - produk yang memiliki impulse buying atau rangsangan pembelian yang tinggi, seperti misalnya : fashion (termasuk baju, sepatu, aksesories, parfume, kosmetik), produk unik yang baru muncul (pasir untuk kucing), DVD, produk yang dibutuhkan di masa depan (produk produk baby untuk janin yang akan dilahirkan nanti), body care product (obat pelangsing), hingga hewan peliharaan (merangsang emotional sense).

1. Stimuli Pemasaran dan Lainnya

Stimuli pemasaran yang paling menarik adalah dengan urutan demikian :

a. Produk - > Sebagian besar narasumber mengaku mencari produk produk yang unik yang ditawarkan di internet, atau produk yang sulit mereka temukan.

Misalnya : sparepart komputer keluaran lama, pasir kucing, makanan unik dari daerah lain, dan lain - lain 
b. Harga

Narasumber tertarik dengan harga yang bersaing dibandingkan dengan toko fisik, karena mereka menilai toko fisik memerlukan banyak biaya untuk pengelolaannya. Biaya pengelolaan yang dimaksud disini adalah sewa tempat, listrik, biaya karyawan, promosi, stok barang, pajak, dan lain - lain. Responden juga menilai karena mereka membeli lewat perorangan, maka mereka bisa mendapatkan harga yang bersaing. Terlebih lagi apabila pembelian dilakukan dalam jumlah banyak.

c. Promosi

Promosi adalah salah satu hal yang dapat menarik konsumen untuk mempelajari lebih lanjut produk yang ditawarkan.

d.Tempat

Tempat memiliki sedikit pengaruh, khususnya apabila konsumen akan membeli barang yang murah dan dalam jumlah sedikit, maka mereka akan memilih teknik COD ( Cash on Delivery). Sedangkan apabila konsumen memang menginginkan produk tersebut, maka konsumen bersedia menanggung biaya ongkos kirim yang dibebankan kepada mereka. Konsumen juga mempertimbangkan faktor tempat dihubungkan dengan barang yang akan dibeli, misalnya : hewan peliharaan.

\section{Black Box Consumer}

Kotak hitam konsumen meliputi faktor pribadi yang ada di dalam pertimbangan konsumen untuk melakukan online shopping, yaitu dari faktor budaya, sosial, personal, dan psikologi.

- Narasumber yang memiliki gaya hidup sibuk cenderung menyukai online shopping, seperti misalnya narasumber 2 dan 3 yang mengaku mereka memiliki kesibukan kuliah atau bekerja, dan mereka baru memiliki waktu luang di saat malam. Akan tetapi ada keterbatasan toko fisik yang memiliki jam operasional tertentu, sehingga tidak memungkinkan mereka untuk jalan - jalan atau melakukan pembelian di toko fisik untuk produk yang menurut mereka memerlukan "survey" pilihan terlebih dahulu. Dengan adanya alternatif online shopping, hal ini memudahkan mereka untuk dapat mencari barang yang mereka inginkan. 
- Selain itu, toko online dimanfaatkan oleh pendatang yang cenderung memiliki keterbatasan atau perilaku tidak pergi ke luar rumah. Hal ini nampak pada responden 5, yang mengaku merupakan pendatang dari Bandung dan saat ini dia tengah hamil sehingga membatasi geraknya untuk pergi ke luar rumah, disamping narasumber tersebut tidak hapal jalan - jalan di Tanjugpinang dan suami yang bekerja memiliki keterbatasan waktu untuk menemaninya. Situasi ini mendukung perilaku belanja online pada responden tersebut.

- Konsumen juga mempertimbangkan membeli barang yang malu dibelinya di dunia nyata, seperti misalnya obat pelangsing. Karakteristik pembelian dari toko online datang berupa paket yang terbungkus rapi, sehingga mereka dapat membukanya sendiri di rumah tanpa ada orang lain yang mengetahui isinya.

\section{Respon Pembeli}

Respon pembeli meliputi pilihan produk dan pilihan merek, serta pilihan penjual yang menentukan waktu pembelian dan besarnya transaksi. Dengan beragamnya produk yang terdapat pada toko - toko online, membuat narasumer dalam riset ini untuk melakukan survey terhadap pilihan - pilihan yang tersedia berdasarkan apa yang cocok dengan selera mereka atau apa yang mereka butuhkan. Mereka pun membanding bandingkan beberapa barang yang terdapat pada pasar online. Mereka pun terpatok dengan jumlah minimal pembelian, misalnya Rp 50.000 yang biasanya menjadi patokan atau mereka pun membatasi pengeluaran / budget untuk belanja online. 


\section{BAB III}

PENUTUP

1. Kesimpulan

Dari riset mengenai perilaku konsumen terhadap online shopping yang telah dilakukan pada 10 narasumber di area sekitar kijang dan Tanjungpinang, didapatkan kesimpulan bahwa :

- Online shopping dipersepsi sebagai sesuatu yang menyenangkan karena praktis oleh narasumber yang sudah pernah melakukan online shopping. Sedangkan pada konsumen yang masih tradisional cenderung menghindari online shopping, karena memiliki persepsi yang menakutkan dan buruk akibat adanya beberapa kasus penipuan berkedok online shopping.

- Faktor yang memotivasi konsumen adalah faktor dalam (kesibukan untuk berbelanja di toko fisik, pertimbangan pribadi, dan lain - lain) dan juga faktor dari luar (produk, harga, dan promosi yang ditawarkan oleh penjual online).

- Online shopping diminati oleh narasumber yang merupakan golongan Generasi Y, yaitu dengan usia sekitar 18 - 34 tahun di tahun 2018 ini.

- Model perilaku konsumen melibatkan beberapa faktor sebelum memutuskan untuk melakukan belanja online, seperti misalnya kepercayaan terhadap penjual, kemudahan teknologi untuk mengakses internet dan menjelajahi toko online, kemudahan pembayaran, pilihan produk yang sulit ditemui di toko fisik, pertimbangan harga, waktu, dan jumlah pengeluaran, dan lain sebagainya. 
Bagaimanapun, riset ini masih memiliki keterbatasan, khususnya dalam ruang lingkup riset yang hanya dilakukan pada 10 narasumber di area sekitar Tanjungpinang dan kijang, sehingga hasilnya kurang dapat menggeneralisasi perilaku konsumen secara keseluruhan. Saran yang dapat dilakukan untuk penelitian yang akan datang adalah :

1. Penelitian / riset yang dilakukan pada skala yang lebih luas dengan jumlah subyek penelitian yang lebih besar.

2. Penelitian yang secara spesifik menuju pada jenis barang atau perilaku konsumen tertentu, misalnya : penelitian mengenai e-ticket pada perilaku belanja online, atau perilaku pembelian ulang pada belanja online. 
[1] David, 1. Loudo dan Albert J. Della Bitta. 1998. Consumer Behavior : Third Edition, New York. Mc-Graw Hill Book Company, 1998.

[2] Engel, James. F. Roger D. Blackwell dan Paul W. Miniard. 2003. Consumer Behavior. 11th Edition. The Dryden Press, Orlando.

[3] Kotler, Philip. 2006. Marketing Management Analysis : Planning, Implementation and Control. New York, Prenticel Hall.

[4] Kotler, Philip. 2006. Marketing Management : An Asian Persepective. Fourth Edition, Singapore, Prenticel Hall, 2006.

[5] Lexy J. Moleong. Metodologi Penelitian Kualitatif. Cetakan ketiga. Remaja RosdakaryaBandung. 1991.

[6] Mulyana, M., 2012. Consumer Behaviour: Sukses Dengan Memahami Konsumen. ISBN 978-979-18531-6-3, Bogor: Kesatuan Press.

[7] Mulyana, Dedy. 2001. Ilmu Komunikasi Suatu Pengantar. Penerbit Rosdakarya, Bandung

[8] Mulyana, M. and Syarif, R., 2007. Analisis Sikap dan Prilaku Konsumen Terhadap Pembelian Produk, Studi Kasus Produk Susu Kental Manis Coklat Indomilk pada Konsumen Jakarta. Jurnal Ilmiah Kesatuan Nomor, 2. Nanawi, Martini. 2002. Penelitian Terapan. Yogyakarta: Gajah Mada Press.

[9] Nurendah, Y. and Mulyana, M., 2012. Analisis Strategi Lokasi Ritel Dan Citra Toko Giant Botani Square Bogor. Jurnal Ilmiah Kesatuan, 14(1), pp.21-32.

[10] Schiffman, L. G. \& Kanuk, L. L. (2007). Consumer Behavior edition. Pearson International Edition. Swasta, Basu. 2002. Azas-azas Marketing. Yogyakarta : Liberty.

[11] Supardi, F., Fadillah, A. and Hakim, L., 2013. Pengaruh Komunitas Pengguna Terhadap Loyalitas Pelanggan. Jurnal Ilmiah Manajemen Kesatuan, 1(2).

[12] Sujana, S., 2004. Pengaruh Penetapan Kemasan Terhadap Tingkat Loyalitas Konsumen: Studi Kasus Pada Perusahaan Pd Nanjung Bogor. Jurnal Ilmiah Ranggagading (JIR), 4(2), pp.92-98.

[13] Hidayat, L., Mulyana, M. and Effendy, M., 2018. Membangun Kepuasan Mahasiswa Pengguna Laboratorium Komputer. JAS-PT Jurnal Analisis Sistem Pendidikan Tinggi, 1(2), pp.93-101.

[14] Kencana, S., FAKTOR-FAKTOR YANG MEMPENGARUHI KINERJA BISNIS USAHA MIKRO, KECIL DAN MENENGAH (UMKM) DI KAWASAN AREA LALU LINTAS SISTEM SATU ARAH (SSA).

[15] Pauziah, P. and Mulyana, M., 2018. Formulation of The Green Marketing Development Strategy for the Body Shop Botani Square Bogor. In THE INTERNATIONAL CONFERENCE ON ACCOUNTING AND MANAGEMENT SCIENCE (p. 171).

[16] Mulyana, M. and Khrisnayoga, P.P., 2019. OBSERVASI PERILAKU KONSUMEN DALAM BERBELANJA ONLINE. 
1. Website Online Shopping apa yang pernah dikunjungi? Sebutkan nama websitenya. Jawaban : Dari 10 narasumber rata rata kunjungi website https://www.lazada.co.id

2. Kapan terakhir melaksanakan transaksi online tersebut? Sebutkan tanggal dan jam-nya Jawaban : Dari 10 konsumen Narasumber yang melaksanakan online di https://www.lazada.co.id diantaranya melakukan transaksi Pada Tanggal 12 November 2018 , Pukul 17.00 Wib

3. Produk apa yang dibeli Jawaban : Produk yang dibeli Misalnya, Narasumber 1 membeli produk - produk sparepart komputer, karena dapat mendukung pekerjaannya sebagai online shopper khusus sparepart komputer maupun pekerjaannya di dunia nyata. Akan tetapi, pembelian pada wanita adalah produk produk yang memiliki impulse buying atau rangsangan pembelian yang tinggi, seperti misalnya : fashion (termasuk baju, sepatu, aksesories, parfume, kosmetik), produk unik yang baru muncul (pasir untuk kucing), DVD, produk yang dibutuhkan di masa depan (produk - produk baby untuk janin yang akan dilahirkan nanti), body care product (obat pelangsing), hingga hewan peliharaan (merangsang emotional sense).

4. Bagaimana cara pembayarannya? (Transfer Online Banking, Transfer ATM, Transfer SMS Banking, Kartu Kredit) Jawaban : Dari 10 Narasumber yang diwawancara ada melakukan transfer online Banking, lewat Mobile banking BCA, Kata 1 narasumber karena lebih efektif pembayarannya, narasumber lain ada yang memakai kartu kredit pembayaran menurutnya bisa mengumpulkan poin kartu kredit, dan ada yang melakukan pembayaran lewat ATM BCA karena ada Bukti Pembayaran fisiknya, Tempat memiliki sedikit pengaruh, khususnya apabila konsumen akan membeli barang yang murah dan dalam jumlah sedikit, maka mereka akan memilih teknik COD ( Cash on Delivery). Sedangkan apabila konsumen memang menginginkan produk tersebut, maka konsumen bersedia menanggung biaya ongkos kirim yang dibebankan kepada mereka. Konsumen juga mempertimbangkan faktor tempat dihubungkan dengan barang yang akan dibeli, misalnya : hewan peliharaan.

5. Apakah harga produk tersebut lebih murah dibanding beli langsung di pasar/toko? Jawaban Dari wawancara 10 Narasumber ada yang bilang harga produk lebih murah dibandingkan beli langsung di Toko atau Pasar misalnya pakaian soal kualitas di https://www.lazada.co.id terjamin dan murah ada yang bilang masalah harga relatif murah tetapi karena praktis tidak perlu kunjungan ke Toko - toko atau tinggal buka website https://www.lazada.co.id semua produk tersedia dan 
praktis didalam memenuhi kebutuhan dan menghemat waktu. Harga Narasumber tertarik dengan harga yang bersaing dibandingkan dengan toko fisik, karena mereka menilai toko fisik memerlukan banyak biaya untuk pengelolaannya. Biaya pengelolaan yang dimaksud disini adalah sewa tempat, listrik, biaya karyawan, promosi, stok barang, pajak, dan lain-lain. Responden juga menilai karena mereka membeli lewat perorangan, maka mereka bisa mendapatkan harga yang bersaing. Terlebih lagi apabila pembelian dilakukan dalam jumlah banyak.

6. Bagaimana cara produk dikirimkan penjual ke konsumen? Layanan apa yang digunakan? Jawaban : Dari wawancara 10 Narasumber rata - rata mereka pesan barang di situs online website https://www.lazada.co.id dikirimi lewat JNE karena JNE cuma membutuhkan 2/3 hari barang sudah sampai dirumah kalau ekspedisi lain memerlukan waktu 1 minggu Harga Narasumber tertarik dengan harga yang bersaing dibandingkan dengan toko fisik, karena mereka menilai toko fisik memerlukan banyak biaya untuk pengelolaannya. Biaya pengelolaan yang dimaksud disini adalah sewa tempat, listrik, biaya karyawan, promosi, stok barang, pajak, dan lain - lain. Responden juga menilai karena mereka membeli lewat perorangan, maka mereka bisa mendapatkan harga yang bersaing. Terlebih lagi apabila pembelian dilakukan dalam jumlah banyak.

7. Kemudahan apa yang dirasakan konsumen saat melakukan transaksi online tersebut Jawaban :Narasumber yang memiliki gaya hidup sibuk cenderung menyukai online shopping, seperti misalnya narasumber 2 dan 3 yang mengaku mereka memiliki kesibukan kuliah atau bekerja, dan mereka baru memiliki waktu luang di saat malam. Akan tetapi ada keterbatasan toko fisik yang memiliki jam operasional tertentu, sehingga tidak memungkinkan mereka untuk jalan - jalan atau melakukan pembelian di toko fisik untuk produk yang menurut mereka memerlukan "survey" pilihan terlebih dahulu.

8. Dengan adanya alternatif online shopping, hal ini memudahkan mereka untuk dapat mencari barang yang mereka inginkan. Selain itu, toko online dimanfaatkan oleh pendatang yang cenderung memiliki keterbatasan atau perilaku tidak pergi ke luar rumah. Hal ini nampak pada responden 10, yang mengaku merupakan pendatang dari Bandung dan saat ini dia tengah hamil sehingga membatasi geraknya untuk pergi ke luar rumah, disamping narasumber tersebut tidak hapal jalan - jalan di Tanjugpinang dan suami yang bekerja memiliki keterbatasan waktu untuk menemaninya. Situasi ini mendukung perilaku belanja online pada responden 
tersebut. Konsumen juga mempertimbangkan membeli barang yang malu dibelinya di dunia nyata, seperti misalnya obat pelangsing. Karakteristik pembelian dari toko online datang berupa paket yang terbungkus rapi, sehingga mereka dapat membukanya sendiri di rumah tanpa ada orang lain yang mengetahui isinya. Tempat memiliki sedikit pengaruh, khususnya apabila konsumen akan membeli barang yang murah dan dalam jumlah sedikit, maka mereka akan memilih teknik COD ( Cash on Delivery). Sedangkan apabila konsumen memang menginginkan produk tersebut, maka konsumen bersedia menanggung biaya ongkos kirim yang dibebankan kepada mereka. Konsumen juga mempertimbangkan faktor tempat dihubungkan dengan barang yang akan dibeli, misalnya : hewan peliharaan.

9. Kesulitan apa yang dirasakan konsumen saat melakukan transaksi online tersebut Jawaban :Sejauh ini belum mengalami kesulitan didalam berbelanja online atau bertransaksi online cuman faktor dari luar produk harga dan promosi yang ditawarkan oleh penjual online. Dari 10 Narasumber sebagian besar nasarumber mengakui mencari produk produk yang unik ditawarkan di internet, atau produk yang sulit mereka temukan misalnya : sparepart, komputer keluaran lama , pasir kucing , makanan unik dari daerah lain, dan lain lain

10. Apakah Anda akan membeli produk lain di web online shopping tersebut? Jawaban Dari 10 Narasumber semuanya membeli produk lainnya di website https://www.lazada.co.id

11. Apakah Anda akan merekomendasikan web online shopping tersebut kepada orang lain? Jawaban : Narasumber selalu merekomendasikan web online shopping tersebut kepada temannya dan keluarga, serta saudaranya karena kualitas Pakaian dan produk lain - lainya. di website https://www.lazada.co.id Terbaik kualitasnya dan Terjamin 